\title{
Entomopathogenic Nematodes Survey, Persistence in Soil, Reproductive Potential and their Effects on Meloidogyne incognita
}

\author{
Khan Y.S. ${ }^{1}$ and Javed N. ${ }^{2}$ \\ ${ }^{1}$ CABI Central and West Asia \\ ${ }^{2}$ Dept. Plant Pathol., Univ. Agric., Faisalabad, Pakistan \\ ${ }^{1}$ Corresponding Author's email: y.khan@.cabi.org \\ ${ }^{2}$ Second Author's email: nazirpp2003@gmail.com
}

\begin{abstract}
The increasing cost of nematicides and environmental deterioration are the great challenges to agriculture. Entomopathogenic nematodes (EPNs) could be a choice as biocontrol agent in suppressing the root knot nematode, Meloidogyne incognita on tomato and other crops. A total number of 75 soil samples were collected from different locations of Vehari and Faisalabad, Pakistan. In Vehari out of 14 sites, 13 sites were found positive for EPNs, Nematodes were recovered from 19 (54\%) of 35 soil samples obtained from ecologically diverse habitats. From University of Agriculture Faisalabad, EPNs were recovered from 6 (40\%) of 15 soil samples. While, out of 25 samples collected from Ayub Agriculture Research Institute 9(36\%) were found positive for EPNs. Both Steinernema and Heterorhabditis species were found in these locations. The soil samples were also analyzed to indicate the effect of soil texture. Maximum EPNs (36 \%) were recovered from sandy loam soil followed by loamy soil. A series of experiments was carried out to unearth EPNs' soil persistence, reproductive potential and their effects on root knot nematodes. All species and strains of EPNs had potential to persist in almost all type of soils. Persistence was observed in sterilized soil sand and clay (1:1). Maximum persistence was found in $S$. glaseri $(29.11 \%)$ followed by $S$. pakistanese $(28.41 \%), H$. indica $(26.93 \%)$, S. asiaticum $(24.42 \%)$, S. feltiae $(21.52 \%)$ and H. bacteriophora $(21.11 \%)$ which showed the least persistence in sterilized soil. All species of both the families Heterorhabditidae and Steinernematidae did not persist more than $30 \%$ in sterilized soil. Reproductive potential of three EPNs was recorded using the greater wax moth Galleria mellonella larvae. $H$. indica showed very high reproductive potential within wax moth followed by $S$. asiaticum and $S$. pakistanese. On the other hand, maximum emerged infective juveniles per day were recovered from $H$. indica followed by $S$. pakistanese and $S$. asiaticum. Suppressive effect of EPNs against root knot nematodes was observed on susceptible tomato cultivars at different concentration. S. pakistanese suppress $M$. incognita population more efficiently than $H$. indica at all the levelsi.e. 1250, 2500 and 5000 nematodes pot $^{-1}$. After 35days egg masses (EM) recovered from S. pakistanese treated pots at level 1250 were 232/pot, at level 2500 were 207 and at level 5000 were 135 respectively. Similarly, egg masses recovered from $H$. indica treated plants at level 1250 were 276 , at level 2500 were 212 and at level 5000 were $154 \mathrm{EM}_{\text {pot }}{ }^{-1}$ respectively. No EM were recovered from clean plants on contrary328 EM were recovered from plants with root knot nematodes only.
\end{abstract}

Keywords: Egg Mass, Root knot Nematode, Entomopathogenic Nematode, Wax Moth 


\section{INTRODUCTION}

Biological control gained momentum as an important part of integrated pest management system for reducing harmful pesticide use. The entomopathogenic nematodes (EPNs) could be a choice from various biological control agents because they are native to many regions throughout the world with broad host range, have no adverse effects on animals and plants. The application is easy to handle with conventional pesticides equipment. Different species of the genera Heterorhabditis and Steinernema are effective biological control agents (e.g. Stock, 2005; AbdElgawad et al., 2017). They are obligate natural parasites of insects and remain in the soil with no feeding until the infective juveniles (IJS) attack their targets to complete the rest of EPNs life cycle in the insect hosts.

Nematicides limited availability and high cost of nematicidal development have created a need to find alternative methods for plant-parasitic nematode management. Development of alternatives to harmful chemical nematicides is priority for the future nematology (Barker et al., 1994). Researchers reported antagonism between EPNs and plant parasitic nematodes (e.g. Ishibashi and Kondo, 1986; Grewal et al., 1997 and 1999; Jagdale et al., 2009; Abd-Elgawad, 2017).

There is no information on pre and post-infestation applications of entomopathogenic nematodes to suppress $M$. incognita on tomato in Pakistan. The objective of this research was to isolate EPNs and to test EPNs persistence in soil, their reproductive potential as well as to evaluate effect of EPNs on $M$. incognita suppression on tomato using two species of entomopathogenic nematodes.

\section{MATERIALS AND METHODS}

\section{Rearing of the greater wax moth (Galleria mellonella $\mathrm{L}$.)}

Galleria mellonela L. were kept in rearing plastic jars $\left(19 \times 12 \times 12 \mathrm{~cm}^{3}\right)$ or in plastic boxes $1500 \mathrm{ml}$ volume $(11 \mathrm{~cm}$ diameter and $15 \mathrm{~cm}$ height). These Jars were covered with lids containing small holes to avoid suffocation or with muslin cloth. Last instars larvae of $G$. mellonela were separated for culturing six EPN species nematode culture imported from England. Fresh laid eggs were transferred to modified artificial diet which was prepared by mixing oat, wheat, rice and maize porridge $(20 \mathrm{~g})$, yeast granules $(50 \mathrm{~g})$ in solution of $80 \mathrm{ml}$ warm honey and glycerol $(100 \mathrm{~g})$. The eggs hatched within 3-4 days. After 5-6 weeks, larvae reached the last instars and were collected to be used in the experiments. Some larvae were left in the jar to pupate. Two weeks later, the adult females emerged and laid eggs. Gallerias reared on this diet were kept at $27^{\circ} \mathrm{C}$ in an incubator.

\section{Multiplication of EPNs in the wax moth}

Wax moth larvae were used as bait for multiplication of entomopathogenic nematodes. Late-instars larvae of the greater wax moth, G.mellonella L. were placed in plastic Petri-dish (9 $\mathrm{cm}$ diameter), lined with two pieces of Whatman filter paper. Two $\mathrm{ml}$ water containing 300 juveniles were added in each Petri-dish. Petri dishes then sealed with Para-film and placed in incubator at $27^{\circ} \mathrm{C}$ in dark for 2 to 3 days until Galleria found dead.

\section{Isolation of IJs from dead Galleria by White trap method}

A modified white trap consisting of a plastic container $\left(9 \times 9 \times 6 \mathrm{~cm}^{3}\right)$ filled with distilled water to a depth of $1 \mathrm{~cm}$ (White, 1927); the bottom of an inverted Petri-dish (5-3.5 $\mathrm{cm}^{2}$ 
depending on plastic container) was placed in container. A sheet of filter paper $(7 \mathrm{~cm})$ was placed on the Petri dish allowing the edge of filter paper to come in contact with water. Afterward, dead larvae were placed on filter paper on the top of the Petri dish and plastic container covered the lid. White traps were further incubated at respective infection temperature until the nematode progeny emerged. Depending on nematode species, IJs started to leave the cadaver 8-20 days after infection. Infective juveniles that moved down through the filter paper into the water were then harvested. Nematode harvested from White trap were collected in beakers, counted and stored in refrigerator at $10^{\circ} \mathrm{C}$ in small plastic containers (Woodring and Kaya, 1988).

\section{Preparation of the root-knot nematode}

Single egg mass of Meloidogyne incognita per each plant was cultured on tomato 'Money Maker' in the greenhouse, then nematode identification was confirmed via perennial patterns of adult females and additional plants were re-infected by $M$. incognita (Taylor and Sasser, 1978). The plants were transferred to big pots $(1.5 \mathrm{~kg})$ and maintained for further three months. Eggs of $M$. incognita to be used as inoculum were extracted using a sodium hypochlorite method (Hussey and Barker, 1973).

\section{Soil samples collection and processing}

Soil samples were collected to isolate EPNs from 13 different locations in Vehari strict Punjab. Samples were also collected from vegetables cultivated area of University of Agriculture Faisalabad and Ayub Agriculture Research Institute. Total 75 samples were collected from diverse habitats of agricultural areas viz. various vegetables fields, e.g. cotton, sugarcane, maize, cauliflower and okra vegetables preferred where insect attack was more. Soil type was also noted during the study. From each location about $500 \mathrm{~g}$ soil sample was collected with a hand shovel from top $10 \mathrm{~cm}$ soil profile within the area of about $1 \times 1 \mathrm{~m}^{2}$.Samples were brought to laboratory and then stored in refrigerator at $10{ }^{\circ} \mathrm{C}$. For isolation of nematodes from soil samples "Galleria trap" method was used (Mracek, 1980). Soil samples were placed in $\left(9 \times 6 \mathrm{~cm}^{2}\right)$ plastic pots, $100 \mathrm{~g}$ in each container. In each pot, five Wax moth G.mellonella larvae were placed in close contact with soil through the pressure of the lid. The pots were incubated for 5 to 7 days at $27{ }^{\circ} \mathrm{C}$. Samples were checked daily and the dead larvae collected from the samples; these larvae were cleaned by tissue paper and rinsed properly with tap water after that these dead larvae were transferred to White traps and identified to the generic level using the color of dead larvae (Woodring and Kaya, 1988).

\section{Experiment1: Persistence of EPNs in soil}

The quantity $600 \mathrm{~g}$ of soil sample consisting of sand and clay (1:1) was mixed thoroughly then autoclaved at $15 \mathrm{psi}$ for $30 \mathrm{~min}$. After that $100 \mathrm{~g}$ of soil samples placed in each plastic pot and the soil in pots was moistened. Total six species of EPNs i.e. Steinernema feltiae, S. glaseri, S. pakistanese, S. asiaticum, Heterorhabditis bacteriophora and H.indica were used with three replications each. Three thousand nematodes of each species were added in each pot. After 2 days these soil samples with EPNs were placed on modified white head trays filled with water. Collections of nematode suspensions were made at various time intervals. Completely randomized design was applied for statistical analysis of the data (Gomez and Gomez, 1984).

\section{Experiment 2: Reproductive potential of EPNs in wax moth larvae}

Three late-instars larvae of G.mellonela were placed in plastic Petri dish $(9 \mathrm{~cm}$ diameter), lined with two pieces of Whatman filter paper. Two ml water containing 
300 IJs were added in each Petri dish. Petri dishes were sealed with para-film and placed in an incubator at $27{ }^{\circ} \mathrm{C}$ in dark for 2 to 3 days until galleria were dead. Three species of EPN were used with three replications each. After the death of Galleria, they were placed on White trap and waited for recovery of EPN juveniles. Collection of IJs in beakers was made every day or otherwise until there was no or very low recovery. Data were analyzed using Duncan's Multiple Range Test.

\section{Experiment 3: Effect of entomopathogenic nematodes on root knot nematode, Meloidogyne incognita}

The culture of $S$. pakistanese and $H$. indica was maintained on the wax moth larvae. One month old 'Money Maker' tomato plants were transplanted into soil within $200 \mathrm{ml}$ plastic pots. Both EPN species were applied at the rate of 1250, 2500 and 5000 individual pot $^{-1}$ at the same time with $M$. incognita. Root knot nematodes were applied at the rate of 1500 second stage juvenile pot $^{-1}$. Plants without any treatment or receiving only root knot nematodes were kept as control. These plants were randomised on a glass house bench at $27-35^{\circ} \mathrm{C}$ and each treatment was replicated five times. Plants were uprooted after 35 days of exposure to root knot nematodes. After washing and taking root-shoot weight, roots were stained in Phloxin B then total number of egg masses was counted. The parameter for the assessment of efficacy of EPN against root knot nematodes were based on number of egg masses/roots, and roots and shoot weight. Data were analyzed using Duncan's Multiple Range Test (Duncan, 1955)

\section{RESULTS AND DISCUSSION}

\section{Collection of EPNs}

Thirteen locations were found positive for EPNs; no EPN was recovered from one site only. Nematodes were recovered from 19 (54\%) of 35 soil samples obtained from ecologically diverse habitats. These nematodes identified as species of Steinernema and Heterorhabditis. From University of Agriculture Faisalabad, EPNs were recovered from $6(40 \%)$ of 15 soil samples. Nematodes isolated from University of Agriculture Faisalabad mostly belong to family Steinernematidae. While, out of 25 samples collected from Ayub Agriculture Research Institute $9(36 \%)$ were found positive for EPNs. Both Steinernema and Heterorhabditis species were found in these locations.

These soil samples were also evaluated for the effect of soil texture on the basis of EPNs distribution. Prevalence of nematodes varied in four soil textures, sandy loam, loam, clay loam and sandy clay loam (Fig.1). Maximum number of EPNs isolates was recovered from sandy loam soils viz. $36 \%$, followed by $20 \%$ in loamy soils. Whereas no EPNs were recovered from clay loam and sandy clay loam soils. Maximum number of EPNs was recovered from maize followed by sugarcane, okra, watermelon and chilies fields. EPNs were also recovered from the soil taken from the root base of pumpkin, brinjal, cabbage, rice and cotton.

\section{Experiment.1 Persistence of EPNs in soil}

Persistence of $S$. glaseri, S. pakistanese, S. asiaticum, $S$, feltiae, $H$. bacteriophora, $H$. indica declined with the passage of days (Table 1). At the end of experiment maximum persistence was found in S. glaseri $(29.11 \%)$ followed by $S$. pakistanese (28.41\%), H. indica (26.93\%), S. asiaticum (24.42\%), S. feltiae (21.52\%) and $H$. 
bacteriophora which showed least persistence (21.11\%) in sterilized soil. All tested species did not persist more than $8 \%$ in sterilized soil. Both Steinernema and Heterorabditis persisted in soil but Steinernema species persisted more in soil than Heterorhabditis.
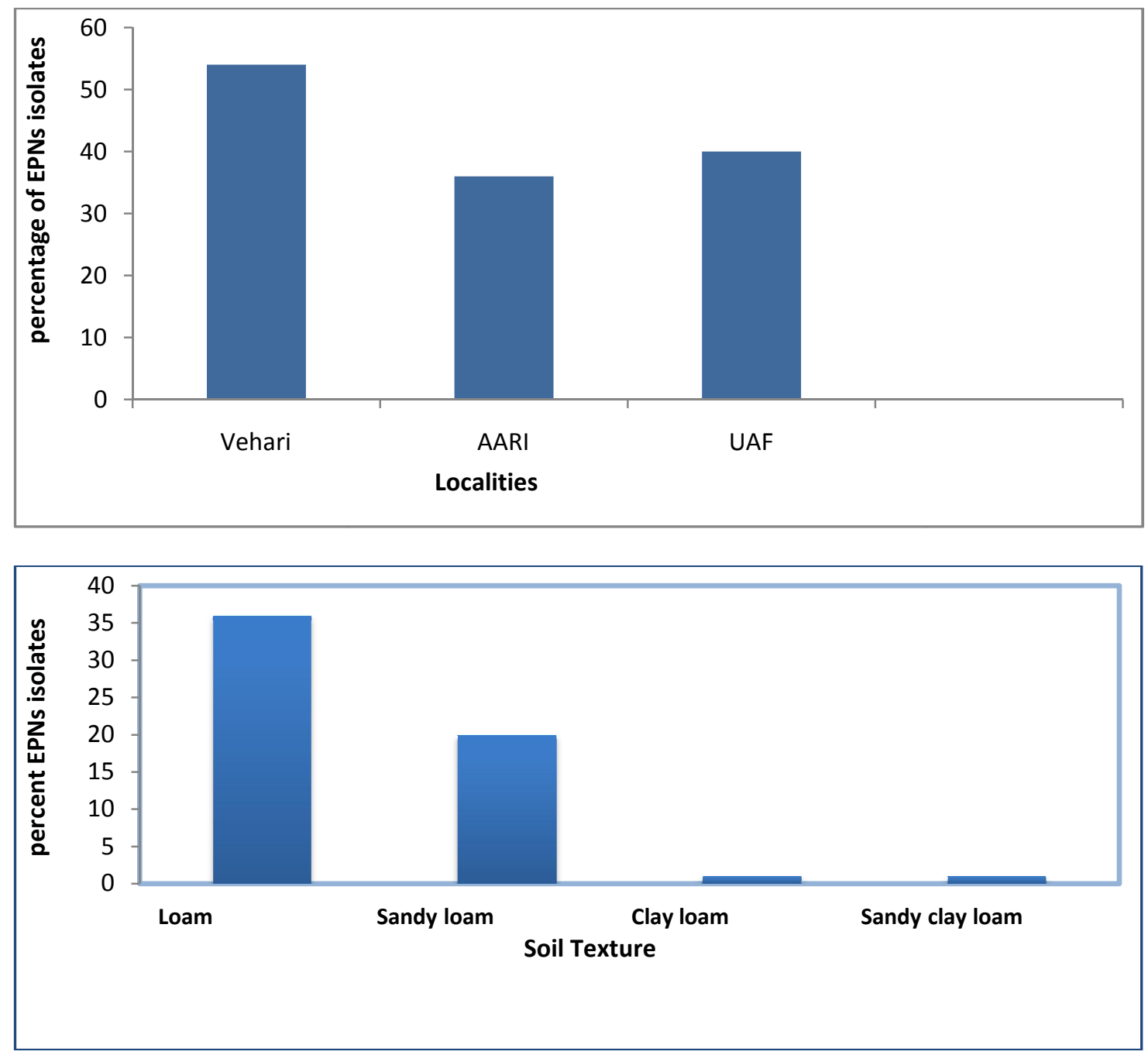

Fig.1.Percentage of recovered entomopathogenic nematode (EPN) isolates relative to localities (upper bar chart) and soil type (lower bar chart). UAF = University of Agriculture Faisalabad; AARI = Ayub Agriculture Research Institute.

On the $6^{\text {th }}$ day of experiment, mean values for different EPNs species rangedfrom 7.87 to $0.62 \%$. Maximum persistence mean value $(7.87 \%)$ was observed in S. glaseri followed by S.pakistanese (6.75\%), S. asiaticum $(5.16 \%)$, S. feltiae (3.08 $\%), H$. bacteriophora $(2.28 \%)$ and minimum mean value was recorded in $H$. indica i.e. $0.62 \%$.

\section{Experiment 2: Reproductive potential of EPN in the wax moth larvae}

Data collected from three different EPN species indicated that emerged IJs among these EPN species were statistically different (Figs.2-4). H.indica showed very high reproductive potential within the insect larvae followed by $S$. asiaticum and $S$. 
pakistanese. Maximum nematodes per day were recovered from $H$. indica. followed by $S$. pakistanese and $S$. asiaticum. Nematodes reproduce themselves within the cadaver by utilizing their symbiotic bacteria which are used as a food source for nematodes. Presumably, EPNs complete two life cycles within the host.

Table 1. Persistence of six entomopathogenic nematode (EPN) species in soil.

\begin{tabular}{|l|c|c|c|c|c|c|c|c|}
\hline EPN Species & Day 1 & Day 2 & Day 3 & Day 4 & Day 5 & Day 6 & Means \\
\hline S. glaseri & $14.08 \mathrm{a}$ & $10.15 \mathrm{~d}$ & $8.513 \mathrm{ef}$ & $7.957 \mathrm{fg}$ & $7.930 \mathrm{fg}$ & $7.870 \mathrm{e}$ & 9.4167 \\
\hline S. pakistanese & $10.99 \mathrm{c}$ & $12.86 \mathrm{~b}$ & $7.307 \mathrm{gh}$ & $6.940 \mathrm{~h}$ & $6.717 \mathrm{hi}$ & $6.753 \mathrm{~g}$ & 8.5945 \\
\hline S. asiaticum & $9.777 \mathrm{~d}$ & $8.613 \mathrm{e}$ & $5.707 \mathrm{j}$ & $5.557 \mathrm{j}$ & $4.250 \mathrm{k}$ & $5.163 \mathrm{j}$ & 6.5112 \\
\hline S. feltiae & $6.913 \mathrm{~h}$ & $6.203 \mathrm{jj}$ & $3.870 \mathrm{k}$ & $4.143 \mathrm{k}$ & $2.477 \mathrm{~lm}$ & $3.080 \mathrm{l}$ & 4.4477 \\
\hline H.bacteriophora & $4.003 \mathrm{k}$ & $4.253 \mathrm{k}$ & $3.097 \mathrm{l}$ & $3.077 \mathrm{l}$ & $2.517 \mathrm{o}$ & $2.283 \mathrm{~lm}$ & 3.2050 \\
\hline H. indica & $2.52 \mathrm{~lm}$ & $2.390 \mathrm{~m}$ & $2.157 \mathrm{mn}$ & $2.273 \mathrm{~m}$ & $1.620 \mathrm{p}$ & $0.6233 \mathrm{no}$ & 1.9306 \\
\hline Means & 8.04717 & 7.41150 & 5.10850 & 4.99117 & 4.25183 & 4.29538 & \\
\hline
\end{tabular}

Each value is a mean of three replicates. Means in a column followed by the same letter are not significantly $(\mathrm{P} \leq 0.05)$ different according to Duncan's multiple-range test.

Graphical representation of $S$. asiaticum showed the reproductive potential of this species within the insect larvae (Fig.2). Two peaks possibly showed the completion of life cycle within the cadaver. If so, S. asiaticum completed two life cycles within the host then came out of the cadaver in millions. S. pakistanese showed the completion of only one life cycle within the host, one peak showed the completion of life cycle and then nematodes came out of the cadaver in millions (Fig.3). Graphical presentation showed that $S$. pakistanese reproduced within the cadaver for 12 days while $S$. asiaticum and $H$. indica completed two life cycles within host in more than 20 days. Graphical presentation of $H$. indica showed the completion of two life cycles within host. Nematodes were recovered from the cadaver more than 20 days (Fig.4). After completion of $1^{\text {st }}$ life cycle nematode recovery was more as compared to $2^{\text {nd }}$ life cycle. Maximum nematodes were recovered from the cadaver infected with $H$. indica. Reproductive potential means for all the three species ranged from 96540.2 to 2790 IJs. All these values of reproductive potential means were statistically different from each other.

\section{Experiment 3: Effect of entomopathogenic nematodes on root knot nematode Meloidogyne incognita.}

Significant suppressive effect $H$. indica and $S$. pakistanese on $M$. incognita was indicated at different EPNs levels on a susceptible tomato cultivar (Table 2). Results showed that $S$. pakistanese suppressed the root knot population more efficiently than $H$. indica at all the tested levels i.e. 1250, 2500 and 5000 nematodes pot $^{-1}$. After 35 days egg masses recovered from $S$. pakistanese at 1250IJs were 232/pot, at level 2500 were 207 and at 5000 IJs were 135. 


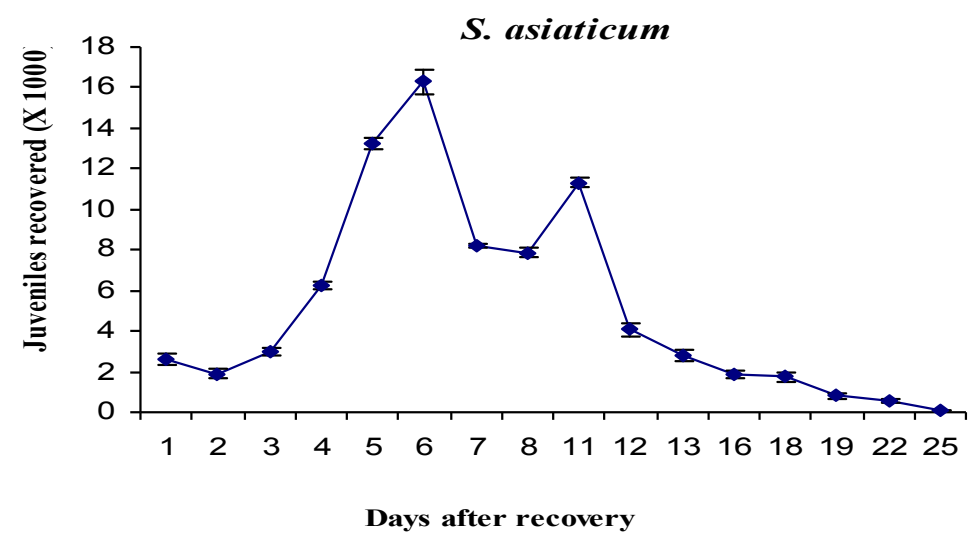

Fig. 2: Reproductive potential of Steinernema asiaticum in Galleria mellonella larvae.

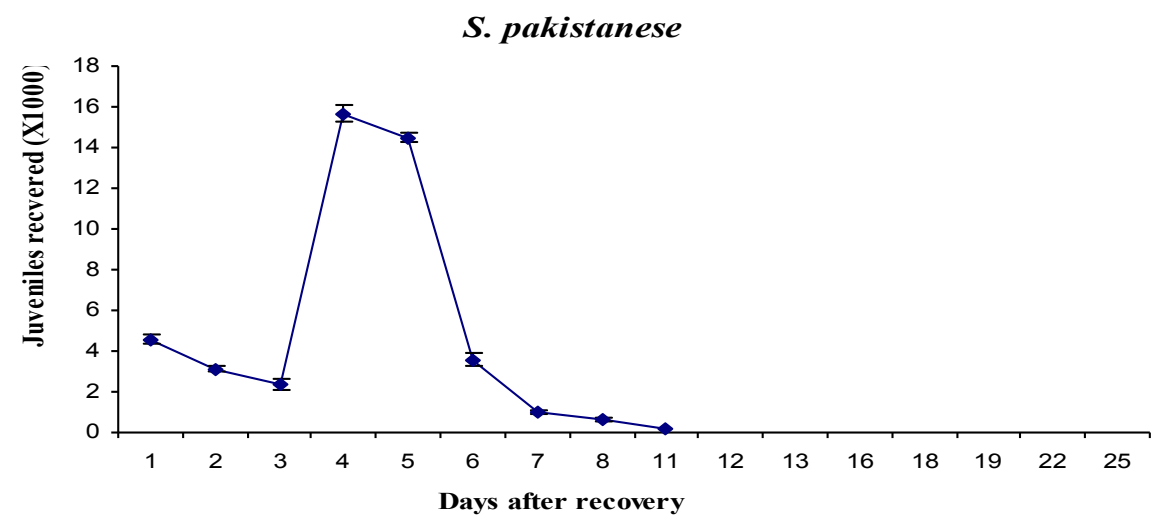

Fig. 3. Reproductive potential of Steinernema pakistanese in Galleria mellonella larvae.

H. indica

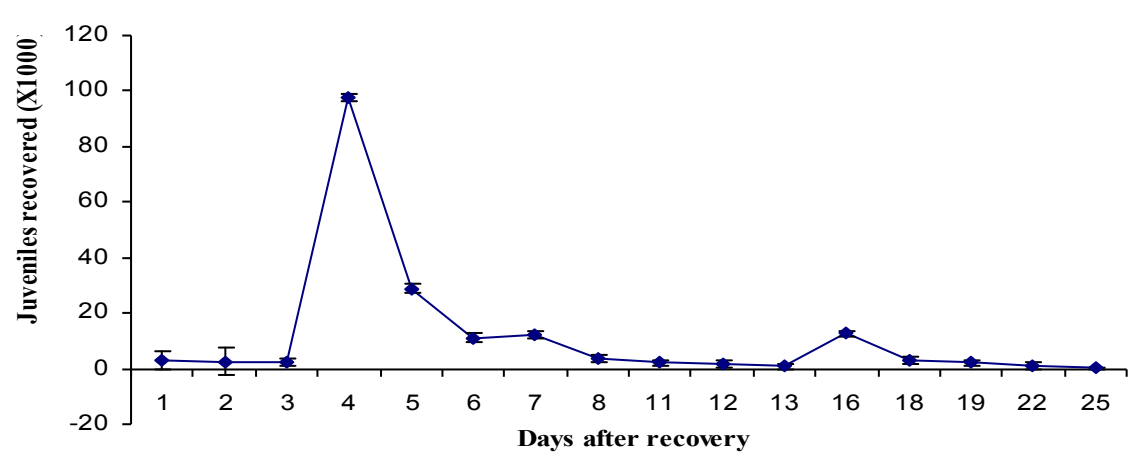

Fig. 4. Reproductive potential of Heterorhabditis indica in Galleria mellonella larvae.

These results showed that high concentration of EPNs suppressed $M$. incognita population efficiently than low concentration. Similarly egg masses recovered from $H$. indica treated plants at level 1250 were 276, at level 2500 were 212 and at level 5000 were $154 \mathrm{EM} /$ pot. On non-infested (clean) plants, no egg masses were recovered and 328 egg masses were recovered from plants with root knot nematode only. 
Table 2. Effect of different densities of entomopathogenic nematode-infective juveniles (IJs) on tomato plant weight and number of root knot nematode, Meloidogyne incognita, egg masses (EM) per root system.

\begin{tabular}{|c|c|c|c|c|c|c|c|c|c|}
\hline \multicolumn{10}{|c|}{ Densities of entomopathogenic nematodes } \\
\hline \multirow[t]{2}{*}{ Treatments } & \multicolumn{3}{|c|}{$1250 \mathrm{IJ} \mathrm{s}$} & \multicolumn{3}{|c|}{$2500 \mathrm{IJs}$} & \multicolumn{3}{|c|}{$5000 \mathrm{IJs}$} \\
\hline & $\begin{array}{c}\text { Root } \\
\text { weight }\end{array}$ & $\begin{array}{l}\text { Shoot } \\
\text { weight }\end{array}$ & $\begin{array}{l}\mathrm{EM} / \\
\text { root }\end{array}$ & $\begin{array}{c}\text { Root } \\
\text { weight }\end{array}$ & $\begin{array}{l}\text { Shoot } \\
\text { weight }\end{array}$ & $\begin{array}{l}\text { EM/ } \\
\text { Root }\end{array}$ & $\begin{array}{c}\text { Root } \\
\text { weight }\end{array}$ & $\begin{array}{l}\text { Shoot } \\
\text { weight }\end{array}$ & $\begin{array}{l}\mathrm{EM} / \\
\text { root }\end{array}$ \\
\hline S. pakistanese & $1.97 \mathrm{a}$ & $4.9 \mathrm{a}$ & $232 \mathrm{a}$ & $2.7 \mathrm{a}$ & $5.1 \mathrm{a}$ & $217 \mathrm{a}$ & $2.1 \mathrm{a}$ & $5.3 \mathrm{a}$ & $135 \mathrm{a}$ \\
\hline H. indica & $2.2 \mathrm{a}$ & $5.4 \mathrm{a}$ & $276 \mathrm{a}$ & $2.3 \mathrm{a}$ & $5.2 \mathrm{a}$ & $202 \mathrm{a}$ & $2.3 \mathrm{a}$ & $5.6 \mathrm{a}$ & $154 \mathrm{a}$ \\
\hline Control (RKN) & $2.4 \mathrm{a}$ & $4.7 \mathrm{a}$ & $328 b$ & $2.4 \mathrm{a}$ & $4.7 \mathrm{a}$ & $328 b$ & $2.4 \mathrm{a}$ & $5.7 \mathrm{a}$ & $328 b$ \\
\hline Clean plants & $2.3 \mathrm{a}$ & $5.1 \mathrm{a}$ & -- & $2.3 \mathrm{a}$ & $5.1 \mathrm{a}$ & -- & $2.3 \mathrm{a}$ & $5.1 \mathrm{a}$ & -- \\
\hline
\end{tabular}

Each value is a mean of five replicates. Means in a column followed by the same letter are not significantly $(\mathrm{P} \leq 0.05)$ different according to Duncan's multiple-range test.

Our identification of the EPN genera relied on the observation of the colour of the cuticle of dead Galleria larva infected by the EPN. That is if the colour of the cuticle of the dead Galleria larva is yellowish that indicates the presence of EPN of Steinernema species. Whereas the colour of the cuticle of the EPN infected dead Galleria larva is brick red means the presence of Heterorhabditis species (Woodring and Kaya, 1988). These EPNs may flow freely in sandy loam soil and have easy way to access insect targets. They may also get sufficient amount of oxygen from soil water in loamy soils. Kung et al. (1990) also reported that nematode persistence declined as soil clay contents increased. Choo et al. (1995) mentioned that EPNs prefered loose soils having humus and rich in organic matter. Recovery of most EPNs from sandy loam and loamy soils in the present study was therefore expected.

Our results also confirmed the findings of Barbercheck et al.(1995) who observed that EPNs offspring highest yield was in corn soil due to the presence of plant secondary metabolites. These results also agreed with the results of Ahmad and Hussain (2002) that conducted a survey of entomopathogenic nematodes in Potowar region of Pakistan and reported the presence of entomopathogenic nematodes in various locations of that area. Both Steinernema and Heterorhabditis species were recovered from the same crops.

Environmental factors that affect nematodes persistence in soil are soil composition, moisture, temperature, and presence of antagonists and competitors. Nematode persistence was prompted in sterilized soil (Kaya, 1990). Generally, Steinernema spp. appears to persist longer than Heterorhabditis spp. under laboratory and field conditions (Baur and Kaya, 2001). In our study persistence, irrespective of soil type was also generally much lower in the Heterorhabditis spp. than in the Steinernema spp. Recovery relative to both Heterorhabditis spp. rapidly declined during the whole days of experiment. The objective of the present study was to develop a method that could estimate nematode occurrence and persistence in soil in a time efficient way. The effect of soil type on infectivity and persistence varied among the six entomopathogenic nematode species and also followed different trends for 
infectivity and persistence. Persistence of $S$. glaseri was highest as compared to all other EPN species; on the other hand H. bacteriophora gave very good results. The tested EPN species persisted well in all type of soils but persistence rate was high in loam, sandy loam and clay loam soils. Previous studies showed lesser infectivity of $S$. glaseri (Kung et al., 1990) and H. bacteriophora in fine textured soils (Choo and Kaya, 1991).This reduction may be correlated to the decreasing pore space between the smaller soil particles that increasingly hinder nematode movement (Wallace, 1958).

Differences in behavior may be more important factors determining the differences in persistence among nematodes species. Molyneux (1985) observed that in the absence of hosts in sandy soil $S$. glaseri but not $H$. bacteriophora often were not moving, continuous positions. This difference in behavior would add to the difference in persistence between $H$. bacteriophora and $S$. glaseri.

Kung et al. (1990) compared nematode persistence in sand, sandy loam, clay loam, and clay and found that $S$. glaseri and $S$. carpocapsae persistence declined from coarser to finer soils. This observation agreed to assume that EPN interaction for survival is influenced by soil type, humidity, and aeration with nematode survival being shorter in finer-textured soils (higher clay content). Smaller pores and higher water-holding capacity in finer soils result in poorer aeration. In less aerated conditions, aerobically respiring (Burman and Pye, 1980) of EPNs inefficiently utilize food material reserves (Croll and Matthews, 1977) and survive for shorter periods. But in our study all species of Heterorhabditis and Steinernema persisted well in mixed soil except $H$. bacteriophora.

In conclusion, our data and those of other studies showed that soil parameters can have different effects on different nematode species, amongst other things depending on behavioral and physiological adaptations of those nematode species. It also became clear that we have to be careful with generalizations across soil types based on a limited number of studies. Soils occur in an almost unimaginable variety. Many more factors can affect nematode performance than just soil particle size composition, $\mathrm{pH}$, and organic matter. For example, different soil nutrients could have positive or negative impacts on nematode performance depending on nematode species, nutrient concentration and exposure length (Jaworska et al., 1999).

The rate of 1250, 2500 and $5000 \mathrm{IJspot}^{-1}$ of $H$. indica and S. pakistanese, suppressed $M$. incognita on tomato plants in growth greenhouse experiment. These findings for Steinernema species agreed with those of Lewis et al.(2001) and showed that the same rate of $H$. indica and $S$. pakistanese also suppressed $M$. incognita on tomato inboth growth chamber and greenhouse trials. Both the symbiotic bacteria like Xenorhabdus spp. for Steinernema and Photorhabdus spp. For Heterorhabditis, may be a factor for $M$. incognita suppression, because these symbiotic bacteria produce metabolites that are toxic to nematodes (Hu et al., 1999). Grewal et al. (1999) reported that repellency, andtoxicity reduced eggs hatch of $M$. incognita exposed to Xenorhabdus spp. cell free extract. They suggested allelo-chemicals produced by Xenorhabdus spp.as the cause of antagonism against the root knot nematodes.

\section{CONCLUSION}

Considering the high cost of chemical nematicides, EPN might be a viable control measure. for some species of plant parasitic nematodes in some crops like tomatoes 
and peanut. Many operators such as the timing of application may be key factors in optimizing their efficacy. Further experiments that account for these factors are needed. Consequently, it is suggested that entomopathogenic nematodes are very efficient bio-control agents in suppressing $M$. incognita on tomatoes.

\section{REFERENCES}

Abd-Elgawad, M.M.M. (2017). Status of entomopathogenic nematodes in integrated pest management strategies in Egypt. In: Abd-Elgawad, M.M.M., Askary, T.H. and Coupland, J. (eds) Biocontrol Agents: Entomopathogenic and Slug Parasitic Nematodes. Wallingford, CAB International, UK, pp. 473-501.

Abd-Elgawad, M.M.M.; Askary, T.H. and Coupland, J. (2017). Biocontrol agents: Entomopathogenic and slug parasitic nematodes. Wallingford: CAB International, $648 \mathrm{pp}$.

Ahmad, S., and Hussain, Z.(2002). Entomopathogenic nematodes associated with soil types and vegetation cover in Pothwar region of Pakistan. Pakistan J.Biol.Sci. 5(6): 640-642.

Barker, K.R., Hussey, R.S.; Krusberg, L.R.; Bird, G.W; Dunn; R.A.; Ferris, H.; Ferris,V.R; Freckman,D.W.; Gabriel, C.J.; Grewal,P.S.; MacGuidwin, A.E; Riddler, D.; Roberts, P.A.; and Schmitt D.P.(1994). Plant and soil nematodes: societal impact and focus for the future. J. Nematol. 26: 127-137.

Barbercheck, M.E., Wang, J. and Hirsh, I.S.(1995). Host plant effects on entomopathogenic nematodes. J. Invertebr. Pathol. 66: 169-177.

Baur, M.E. and Kaya, H.K. (2001). Persistence of entomopathogenic nematodes. In: Baur, M.E. and J.R. Fuxa, (Eds.), Factors affecting the survival of entomopathogens. Southern Cooperative Series Bulletin 400.

Burman, M. and Pye, A.E. (1980). Neoaplectana carpocapsae: respiration of infective juvenile. Nematologica 26: 214-219.

Choo, H.Y. and Kaya, H.K. (1991). Influence of soil texture and presence of roots on host finding by Heterorhabditis bacteriophora. J. Invertebr. Pathol. 58: 279280.

Choo, H.Y., Kaya, H.K. and Stock, S.P.(1995). Isolation of entomopathogenic nematodes (Steinernematidae and Heterorhabditidae) from Korea.Jpn. J. Nematol. 25:44-51.

Croll, N.A. and Matthews, B.E. (1977). Survival of nematodes. In: Croll, N.A. (Ed.), Biology of Nematodes. Wiley, New York, pp. 152-165.

Duncan D.B. (1955). Multiple range and multiple, F-test.Biometrics 11:1- 42.

Gaugler, R.; Grewal, P.S.; Kaya, H. and Smith-Fiola, D. (2000). Quality assessment of commercially produced entomopathogenic nematodes. Biol. Control 17: 100109.

Georgis, R. and Gaugler, R. (1991). Predictability in biological control using entomopathogenic nematodes. J. Econ. Entomol. 84: 713-720.

Gomez, K.A. and Gomez, A.A.(1984). Statistical Procedures for Agriculture Research. $2^{\text {nd }} E d$, June Wiley \&Sons. Inc. New York.

Grewal, P.S.; Martin, W.R.; Miller, R.W. and Lewis, E.E. (1997). Suppression of plant-parasitic nematode populations in turfgrass by application of entomopathogenic nematodes. Biocontrol Sci. Techn.7:393-399.

Grewal, P.S.; Lewis, E.E. and Venkatachari, S.(1999). Allelopathy: a possible mechanism of suppression of plant-parasitic nematodes by entomopathogenic nematodes. Nematology 1: 735-743. 
Haukeland, S.(1993). Entomopathogenic nematodes found in Norway. Norwegian J. Agric. Sci. 7: 17-27.

Hussey, R.S. and Barker, K.R. (1973). A comparison of methods of collecting inocula for Meloidogyne spp., including a new technique. Plant Dis. Rep.57: 1025-1028.

Hu, K.; Jianxiong L. and. Webster, J.M. (1999). Nematicidal metabolites produced by Photorhabdus luminescens (Enterobacteriaceae), bacterial symbiont of entomopathogenic nematodes. Nematology 1: 457-469.

Ishibashi, N. and Kondo, E. (1986). Steinernema feltiae (DD-136) and S. glaseri: Persistence in soil and bark compost and their influence on native nematodes. J. Nematol. 18:310-316.

Jagdale, G.B.; Kamoun, S. and Grewal, P.S (2009). Entomopathogenic nematodes induce components of systemic resistance in plants: biochemical and molecular evidence. Biol. Control 51: 102-109.

Jaworska, M.; Ropek, D. and Tomasik, P. (1999). Chemical stimulation of productivity and pathogenicity of entomopathogenic nematodes. J. Invertebr. Pathol. 73: 228-230.

Kaya, H.K. (1990). Soil ecology. PP. 93-115 in R. Gaugter and H. K. Kaya, eds. Entomopathogenic nematodes in biological control.Boca Raton, Florida, USA,CRC Press.

Kung, S.P.; Gaugler, R. and Kaya, H.K. (1990). Influence of soil pH and oxygen on persistence of Steinernema sp. J. Nematol. 22:440-445.

Lewis, E.E.; Grewal, P.S. and Sardanelli,S. (2001). Interactions between Steinernema feltiae-Xenorhabdus bovienii insect pathogen complex and root-knot nematode Meloidogyne incognita. Biol. Control 21:55-62.

Molyneux, A.S. and Bedding, R.A. (1984). Influence of soil texture and moisture on the infectivity of Heterorhabditis sp. D1 and Steinernema glaseri for larvae of the sheep blowfly, Luciliacuprina. Nematologica 30: 358-365.

Mracek, Z.(1980). The use of "Galleria traps" for obtaining nematode parasites of insects in Czechoslovakia (Lepidoptera: Nematoda, Steinernematidae). ActaEntomol.Bohemoslovaca 77:378-382. Institute of Entomology, Academy of Science of Czech Republic.

Selvan, S.; Gaugler R. and Lewis, E.E. (1993). Biochemical energy reserves of entomopathogenic nematodes. J. Parasitol. 79:167-172.

Shapiro, D.I.; McCoy, C.W.; Fares, A.; Obreza, T. and Dou, H. (2000). Effects of soil type on virulence and persistence of entomopathogenic nematodes in relation to control of Diaprepes abbreviatus. Environ. Entomol. 29:1083-1087.

Stock S.P. (2005). Morphology and systematics of nematodes used in biocontrol. In: Grewal PS, Ehlers R-U, Shapiro-Ilan, D.I., editors. Nematodes as biocontrol agents. New York: CABI; pp. 3-43.

Taylor, A.L. and Sasser, J.N. (1978). Biology, identification and control of root-knot nematodes (Meloidogyne spp.) Raleigh, North Carolina State Univ. Graphics, $\mathrm{NC}$, USA.

Wallace, H.R. (1958). Movement of eelworms. Ann. Appl. Biol. 46: 74-85.

Wallace, H.R. (1971). Abiotic influences in the soil environment. In: Zuckerman, B.M., Mai, W.F., Rohde, R.A. (Eds.), Plant Parasitic Nematodes, vol. I. Academic Press, New York, pp. 257-280.

White, G.F. (1927). A method for obtaining infective nematode larvae from cultures. Sciences 66: 302-303. 
Woodring, J.L. and Kaya, H.K. (1988). Steinernematid and Heterorhabditid Nematodes : A Handbook of Biology and Techniques. Southern Cooperative Series Bulletin 331, Arkansas Experimental Station, Fayetteville, Arkansas. 